\title{
Alayna Cole
}

\section{Smashing the heteropatriarchy: Representations of queerness in reimagined fairy tales}

\begin{abstract}
Fairy tales rely on conventions that perpetuate heteropatriarchal ideals, which makes this an apt genre for deliberate modification to better represent queer perspectives. This article surveys queer reimaginings of the fairy tale published between 1997 and 2010, identifying several problems with representations of queerness and sexuality in existing literature. This canon often works to distance and marginalise those who do not fit the dominant stereotype of a monosexual identity. Further, the frequent depiction of explicit sexual acts, violent and unhealthy relationships, and inappropriate language has worked to exclude young adult audiences. In this article, I identify a growing but still relatively small field of new queer fairy tale literature directed at young adults since 2015: texts that tend to posit the importance of self-identification. Nuanced representations of queer characters in recent young adult fiction make space for the lived experiences of queer youth and have the potential to influence future queer reimaginings of fairy tales, as well as to challenge heteropatriarchal conventions in other genres.

Keywords: sexuality - gender - representation - plurisexuality
\end{abstract}

\section{Introduction}

The fairy tale canon - which, within this paper, refers to the traditional European literary works of authors Charles Perrault, Jacob and Wilhelm Grimm, and Hans Christian Andersen - features conventions that perpetuate heteropatriarchal ideals. These conventions - such as the marriage of the hero, the infrequent naming of characters, the use of distant and impersonal narrators - limit the ability of readers with diverse sexualities and genders to form understandings of their own identity and place within Western society, while simultaneously contributing to societal attitudes that negatively impact on the queer community. Though some contemporary works have made attempts to subvert heteropatriarchal conventions - such as feminist and queer reimaginings of the fairy tale canon written for the adult market - there has typically been an emphasis on representing monosexual characters and behaviours, with few stories exploring the fluidity of sexuality and gender, and the resulting possibility for plurisexual identities [1].

The fairy tale canon contains villainous characters who are typically depicted as antagonists because their actions are 'constructed as negative and threatening to the heteropatriarchal order' (Baker 2010: 81). These figures are often 'monstrous (witches, giants, beasts) and, in that they resist or transgress heteronormative gendering and sexuality, can be described as queer' (Baker 2010: 81). While the fairy tale canon contains these 'monstrous queer' 
antagonists, this 'queerness' is not made explicit through discussions of sexuality or gender, and is rarely positioned in a way that could be interpreted as positive or heroic.

In contrast, feminist fairy tales use more explicit representations of diverse sexualities as a way of combatting heteropatriarchal ideals from the fairy tale canon. However, incorporating same-gender-attracted characters in feminist tales is a way of using ambiguity to disrupt patriarchal gender roles and the conventional resolutions of the fairy tale canon that can disempower women, rather than being a comment on the sexuality of characters themselves (Orme 2010: 117).

Collections of queer fairy tales, which I will discuss in more detail below, also work to destabilise heteropatriarchal conventions of the fairy tale canon. I argue that their representation of queer identities is often less symbolic and more literal than that within feminist tales, as they are also seeking to represent and appeal to queer audiences, and that therefore these queer reimaginings of the fairy tale genre have the potential to demonstrate the variation and diversity within queer identities.

\section{Methodology and Methods}

This paper is informed by the cyclical research-led practice and practice-led research that inspired the writing of my creative work, Queerly Ever After, a collection of short stories designed to emphasise the self-identification of plurisexual women and submitted as part of my doctoral thesis at the University of the Sunshine Coast (Cole 2018). The early development of this work was informed by research-led practice, particularly through the use of research methods like textual analysis and discourse analysis (Smith \& Dean 2009: 7). After foundational research was completed, the 'exploratory cycle of reading, writing, testing, reading, rewriting and retesting' (Brien 2006: 57) that is indicative of practice-led research commenced, with praxis revealing questions that needed to be addressed to meet this project's research aims. In identifying and addressing these knowledge gaps, the process of scholarly research recommenced and the cyclical nature of research-led practice and practice-led research became clear.

Textual analysis - in the form of both close reading and distant reading - was a pivotal research method in writing Queerly Ever After, and is the key research method for this article. Distant reading involves looking at a wide range of texts, focusing on devices, themes, and tropes, as well as larger characteristics like genres and systems (Moretti 2013: 48-9). I applied this method to the European fairy tale canon, queer fairy tales, coming-out stories, feminist fairy tales, and young adult fiction to learn from the similarities and differences of these texts. Distant reading also helped determine conventions, themes, and character stereotypes that are common within each of these categories, informing the choice of narrative elements to replicate, subvert, and challenge within my own creative work.

After employing distant reading techniques to establish patterns, close reading was used to analyse specific texts, searching for hidden meanings in the narrative conventions that have been used (Best \& Marcus 2009: 1). This aspect of textual analysis is an indispensable technique for all disciplines that seek to understand texts (Belsey 2005: 157). Close reading helps identify the problematic elements within existing queer fairy tales, allowing these to be challenged in my own creative work, and to be compared with other genres and 
forms. A number of queer tales and collections were identified through distant reading and analysed with close reading, and will be referenced within this paper, including: Berman's So Fey: Queer Fairy Fiction (2007); Cashorali's Fairy Tales: Traditional Stories Retold for Gay Men (1997a) and Gay Fairy \& Folk Tales: More Traditional Stories Retold for Gay Men (1997b); Holden's A Twist of Grimm: Erotic Fairy Tales for Gay Men (2010); Lowe, Hooper and Diviney's Polluto 4: Queer and Loathing in Wonderland (2008); and Vanderhooft, Valente, YellowBoy and Talbot's Sleeping Beauty, Indeed and Other Lesbian Fairytales (2006).

\section{Queer Fairy Tales}

Among recent collections of queer fairy tales I have surveyed through close and distant reading, there are some examples of characters explicitly defining their own sexualities and labels - particularly in So Fey - such as a character referring to themselves as a 'self-defined faerie' in 'Attracting Opposites' (Frick 2007: 229). Similarly, the protagonist in 'Two Sisters' explicitly notes that she had 'never been interested in boys' (Holsen 2006: 21), and Rem in 'Isis in Darkness' has the following discussion:

"We all do that," said Rem. "That's how we spell it. 'Cause we're not regular orphans. You know that." "You mean not straight," said Isis... "Yeah. There are women and there are womyn. There are boys and there are bois. Girls and grrls. Same here. We're orphyns, not orphans.” (Barzak 2007: 198)

Despite these selected examples, it is more common in these collections for sexuality to be indicated solely by behaviour, rather than by a character's selfidentification. The behaviours depicted range from involvement in a samegender relationship to explicit portrayals of sexual acts between same-gender participants. For example, the protagonist in 'The Queer Kingdom', from $A$ Twist of Grimm, 'looked upon the old man and witnessed a stirring in the old man's trousers. He then knew what he could offer the old man as payment for the night' (Holden 2010). At the resolution of this tale, sexual acts are supposed to save the village and remove a spell, but there is no confirmation whether this works or justification as to why the characters expect that it will.

Similarly, sexually explicit acts are seen in 'Detox', from So Fey, when characters

screw in the handicapped stall while bass thumps in walls and floor and pussy. It's crowded and sweaty, and she can barely smell sex over stale cigarette pong, the broken toilet next door, and horrific cherry disinfectant. The sex is hot anyway. (Potter 2007: 114)

Sexually explicit acts also feature in 'Alice in the Palace', from Queer and Loathing: 'Queen of Tarts is on her knees. Flat as a pancake. Stuffing my cock into her gummy mouth. The King crawls up behind me and rams something in. In. IN!' (Migman 2008: 3). Sexual acts described in similar ways feature across the collections in my sample.

The common reliance on sexually explicit scenes is coupled with the frequent use of profanities and descriptions of violence, with the collections in my sample featuring a number of unhealthy, non-consensual and violent relationships or sexual acts. 'Exiles' features homophobic violence against the protagonist (Meriwether 2007: 245), 'Prince Lindworm' involves a man 
whipping his partner with IV tubing (Cashorali 1997b: 123), 'Paint the Town' involves dancing in a woman's blood (Pinckard 2008: 61), 'A Faun's Tale' contains violent consensual sex that is referred to as 'sacrifice' (Cardamone 2007: 15), and 'Beta Child, Gamma Child' involves non-consensual and violent fellatio where a crying Rebecca's lips and nose are bruised (Edwards 2008: 56). There are rape scenes in 'The Kings of Oak and Holly' (Woods 2007: 107), 'The Mute Princess' (Grant 2006: 47) and 'Heart of Cement' (Dagstine 2008: 90), with the latter being particularly violent, and ending with the victim's death.

By focusing more on behaviour than self-identity, these collections of queer fairy tales are prioritising the titillation of audiences over the empowerment of those being represented and also over increasing understanding and empathy among those who are not. While this may be a prerogative of their creators, it does leave a gap in the literature for more empowering and progressive queer reimaginings of fairy tales, and it is this gap I attempt to address with my own creative work, Queerly Ever After. The use of sexual acts, profanity and violence within recent queer collections also positions them as being intended for adult audiences; by doing so, these collections imply that sexuality and sexual identity are concepts that can only be considered by an adult audience.

In contrast, Queerly Ever After does not include any explicit sexual acts, profanity, or violence in its depiction of diverse sexualities and genders. Although my creative artefact is not specifically designed for an audience of children, the collection also deliberately does not exclude this audience. Since fairy tales are already a space where children explore their identities including their sexual identities and their understanding of gender, sexuality and sex or gender roles (Cranny-Francis 1992: 74-5; Curatolo 2012: 3; Zipes 1999: 75) - Queerly Ever After seeks to incorporate diverse perspectives within the existing fairy tale space, rather than reimagining this space and these explorations of identity as one that excludes children.

\section{Young Adult Fiction}

My survey of queer fairy tales unearthed few reimaginings that have been written in a way that children or young adults can easily engage with and learn from, despite fairy tales traditionally being a space that children can use to help form their identities. However, there has been a rise in young adult fiction that explores varied sexualities and genders. One recent study notes a quadrupling of the number of queer characters published in young adult fiction in the United States between 2010 and 2013 (Jiménez 2015: 408) and these representations can be learned from as an alternative approach to sexualised or violent 'adult' representations of queerness.

Although these numbers are increasing, there are significantly more representations of queer men in young adult fiction than queer women; Jiménez (2015: 408) refers to a study conducted by author Malinda Lo (2011), which states that $50 \%$ of queer representation in young adult fiction published in the United States between 2000 and 2011 was of queer boys, and only $25 \%$ was of queer girls (with the remaining percent being distributed between adult characters, multiple characters, and characters with nonbinary genders).

When referencing this study, Jiménez states that this means $25 \%$ of queer representation in young adult fiction (which she approximates to be $0.07 \%$ of all books published in 2010) are of lesbian girls, erasing the possibility that these queer girls could be queer in other ways - including plurisexual (2015: 
408). Due to this conflation, it is difficult to determine exactly how many books within this percentage include representation of plurisexual girls, but it is safe to assume that the overall number of young adult fiction books published each year that include plurisexual girls - though increasing - remains incredibly low.

However, the young adult fiction featuring plurisexual girls that does exist is representing sexuality in significantly more interesting and nuanced ways than tends to have been evidenced in queer fairy tales for adults. For example, Adaptation by Malinda Lo (2012) - as well as its sequel, Inheritance (Lo 2013) - features a bisexual protagonist named Reese, who explicitly declares her bisexuality in dialogue. Lo says of Reese that 'she chooses to identify that way herself; she says it out loud. It's on the page, deliberately' (2018).

This decision places Adaptation and Inheritance in contrast with another of Lo's young adult novels - Ash (2009) - which has been described as 'lesbian Cinderella' (Lo 2018). In some ways, Ash follows a similar narrative trajectory to the fairy tale canon's Cinderella (Grimm \& Grimm 2013; Perrault 1969) including a stepmother and a prince - but the story also deviates into broader fantasy, drawing on a range of techniques from outside fairy tales and incorporating many additional characters, settings and plot events. Although the protagonist, Ash, is referred to online as a 'lesbian', she is bisexual according to the book's author (Lo 2018); however, bisexuality is explored little in the text itself. The primary evidence of Ash's sexuality is through her relationship with a Kaisa - a noblewoman and huntress. Ash is set in a world where queerness is not frowned upon, which allows Ash to explore her sexuality without judgement in a way that might not be indicative of real life, but it does allow readers to engage with how a teenager might live if their sexuality is accepted by those around them.

Another young adult novel featuring a bisexual protagonist is Love in the Time of Global Warming by Francesca Lia Block (2013), which follows a group of queer teenagers - who represent a range of diverse sexualities and genders - in a dystopian future. Although this text involves a romantic relationship between the protagonist (Pen) and a trans boy (Hex), the focus of the narrative is how these two characters and their companions - Ez and Ash - must work together to save the world.

Plurisexuality is a more central theme in the narrative of The Bermudez Triangle (since republished as On the Count of Three) by Maureen Johnson (2005), which follows Avery as she discovers her own bisexuality and her attraction to her friend Mel. This book relies on some problematic stereotypes about plurisexuality, such as plurisexuals being addicted to sex and always having a fluid or uncertain approach to their sexuality, but Johnson has since suggested that these were attempts to capture the uncertainty that Avery felt about her own sexuality, rather than being a comment on plurisexuality more broadly (Johnson 2013).

Rather than being about the discovery of the protagonist's sexuality, Our Own Private Universe by Robin Talley (2017) is about Aki's sexual experimentation; Aki is certain that she is bisexual when the novel begins. This differs from many of the aforementioned young adult fiction novels, which even when set in science fiction or fantasy landscapes - tend to focus on a character 'coming out' as part of the narrative.

The works I have surveyed by Lo (2012; 2013), Block (2013), Johnson (2005) and Talley (2017) explicitly label the key protagonists' sexuality. Such texts allow characters to display their sexuality in a society where it is not vilified, 
tell stories where queerness is present but is not the central theme, explore biphobic stereotypes, and to sometimes show characters who are already comfortable with their sexuality. Each provide readers with different facets of understanding queerness and can therefore help young adult readers understand themselves or empathise with others in different ways.

\section{Self-identification and Sexuality}

Plurisexual women featured in the creative work that comprises my doctoral thesis, Queerly Ever After, explore their sexualities in varied ways, with some being comfortable in their sexuality at the beginning of their tale, while others use their narrative to explore and better understand their identities. In each of these varied tales, Queerly Ever After seeks to demonstrate that selfidentification of characters is more important than the assumptions of sexuality and gender that external parties (including other characters and the reader) can make based on an individual's visible behaviour or relationships. To demonstrate this, I have ensured that the plurisexual protagonists in each of my stories have sexualities that exist outside of any relationships they foster or retain, each sharing their internal negotiation of their own identity with the reader.

Self-identification reflects practices within the queer community. Orndorff believes that it is important for members of the queer community to define their own sexuality, as this helps to address heteronormativity and encourages society to incorporate varied relationship models into its conceptualisation of 'human intimacy' (Orndorff 1999). Queer individuals cannot be categorised by others based on their relationships or behaviour, or even past attractions, particularly because identities can change over time (Ochs 2009). The only accurate way to learn a person's sexual identity is for them to define themselves (Eisner 2013: 20).

In a study conducted by Callis, self-identification is emphasised as a way of locating the multitude of labels the queer community use to identify themselves (2014). Individuals involved in the study were given the power to identify themselves with any terms they felt were appropriate, and used labels such as 'queer, bisexual, pansexual, bi-curious, heteroflexible and "mostly heteroflexible"' (Callis 2014: 65). Some 'identified with more than one label' or 'chose not to label at all' (65). These labels can be chosen playfully as an act of subversion, such as someone acknowledging attraction to multiple genders while still using a monosexual label (Ochs 2009); this does not invalidate the labels and identities chosen by queer people, yet further emphasises why assumptions should not be made based on behaviour or relationships.

Callis's study suggests that identifying sexuality through sexual behaviour or relationships does not accurately represent the ways the queer community defines sexuality (2014: 65). To ensure the accuracy of my understanding of the queer community's priorities and the way individuals within this community identify themselves, I have used discourse analysis to evaluate the significance of language choices and representations (Cole 2016). This analysis attempts to address the way discussions about representation in scholarly publications are often delayed when compared to what is presently occurring within the queer community (Hale 1997: 223).

Online blogs and opinion pieces written by members of the queer community reveal frustration at assumptions and mislabelling regarding their sexuality and identity. Ford explains that when a plurisexual person dates somebody on a 
long-term basis, this can lead to others assuming they have either become or have always been monosexual (2015). In response to this, she states that her 'queer identity is not defined by who [she is] dating', but she also mentions that when she corrects people who have false expectations, she is made to feel guilty about an unintentional deception 'based on a projection of the other person's assumption' (Ford 2015).

This experience is labelled by Wiest as the act of 'sexual profiling', where society attempts to fit others into categories using assumptions based on behaviour and relationships, or even a person's appearance (2013). People frequently attempt to label the sexuality of others based on their behaviour or appearance (Martin 2015), but who a person can be attracted to or have romantic feelings for does not rely on these factors (Martin 2015; Wiest 2013).

These identity assumptions are problematic, as they often align with sexuality and gender norms and thus perpetuate oppressive heteropatriarchal expectations (Trooien 2016). This oppression needs to be challenged, as nobody should be disempowered by the labels of others or be expected to adhere to a template construction of an identity (Martin 2015).

\section{Plurisexuality and Stereotypes}

Although many of the queer fairy tales, including works for young adults, that I have surveyed in this article attempt to destabilise some of the aforementioned societal expectations, they also often rely on stereotypes. Some stereotypes resemble character archetypes that reflect reality, but many are problematic in their perpetuation of a societal expectation or 'template' of how individuals with certain sexualities and genders should behave.

For example, in collections explicitly 'for gay men', some men are depicted as wearing dresses (Cashorali 1997a: 42; 1997b: 11) and wanting to fill roles such as 'charwoman', 'laundry woman', or 'milkmaid' (Cashorali 1997a: 19). Their femininity is also depicted through their use of language like 'honey' and 'hon' (Cashorali 1997a: 32, 54, 140). Stereotypes of gay men being muscular and obsessed with body image are also perpetuated by these stories (Cashorali 1997a: 28, 45). These behaviours reflect character archetypes evident in the queer community and, despite being stereotypical, are not necessarily harmful when depicted alongside other, differing representations of queerness. In contrast, however, some of the works I have surveyed also perpetuate a number of the problematic stereotypes that are often attributed to plurisexuals, which Eisner (2013: 36-8) lists in Bi: Notes for a Bisexual Revolution, such as: plurisexuals are slutty, promiscuous, or unfaithful; plurisexuals are confused, indecisive, or going through a phase; plurisexuals are actually straight or gay, or have the privilege of being able to choose; and plurisexuality does not exist. In the few instances where plurisexual characters are present in the queer tales I have surveyed, their representations are often perpetuating these stereotypes.

One scene in 'Queer and Loathing on the Yellow Brick Road' features the protagonist thinking, 'Maybe I'd pop by sometime when the missus wasn't around and offer him a little neighbourly comfort' (Hoag 2008: 34). This stereotype of plurisexual people cheating or being promiscuous is also evident when the protagonist's girlfriend declares that 'every person who volunteers gets a free date with [the protagonist]', with the expectation being that the protagonist will comply. Similar scenes of promiscuity potentially against the will of the plurisexual character are seen in 'Detox', where it is said that, 'The car valet eats out her pussy in the back seat when she picks up her car, even 
after she explains she's gay and doesn't want to fuck him' (Potter 2007: 114). Less sexually explicit promiscuity also features in 'Attracting Opposites', where it is said that, 'Faeries do sleep with anyone or anything, if that is what they want' (Frick 2007: 228).

Plurisexuality is represented as a 'phase' in 'The Coat of Stars', where a man says that he has had both boyfriends and girlfriends because 'When you don't know what you're searching for ... you have to look absolutely everywhere' (Black 2007: 156). This character may have a fluid sexuality that allows them to move between 'phases' of attraction, but without explicitly addressing it, it is easy for an audience to misread this representation as indicative of all plurisexual people, thus perpetuating existing stereotypes.

The stereotype that a plurisexual person is actually straight or gay, and that when they enter a committed relationship they can no longer consider themselves plurisexual because they have 'chosen a side' (Eisner 2013: 36) also features in the collections I have surveyed. Tales such as 'A Scent of Roses' (Lundoff 2007) and 'Three Letters from the Queen of Elfland' (Monette 2007) depict women who have loved men and women, but when they choose to leave their male partners to be with the (fairy) women they once loved, they denounce their love for men entirely rather than embracing a plurisexual identity.

Other problematic representations of plurisexuality exist in the literature, such as the representation of incestuous plurisexuality in 'From Asphalt to Emeralds to Moonlight', where a brother and sister are depicted as having a romantic relationship with each other, as well as the female protagonist (Kaye 2007: 135).

While the plurisexual representation that does exist in queer fairy tales often relies on stereotypes, typically, plurisexual perspectives are simply not included at all. Plurisexuality is rarely catered for in these types of tales, which is evident in their titles: collections such as Fairy Tales: Traditional Stories Retold for Gay Men (Cashorali 1997a), Gay Fairy \& Folk Tales: More Traditional Stories Retold for Gay Men (Cashorali 1997b) and A Twist of Grimm: Erotic Fairy Tales for Gay Men (Holden 2010) are explicitly directed towards 'gay men', while Sleeping Beauty, Indeed and Other Lesbian Fairytales (Vanderhooft, Valente, YellowBoy \& Talbot 2006)are explicitly described as 'lesbian'.

Dedicating a text to exploring the perspectives of a specific identity or group of identities is not inherently negative; however, within the body of these texts, there is limited - if any - reference to the self-identities of the characters they are depicting. The romantic relationships depicted in these tales are between people of the same gender, but there is no clear indication that these people are monosexual - other than through the use of monosexual titles. Limiting a narrative's audience to only monosexual readers is unnecessary; it can be speculated that this is an attempt to specifically target a niche market, and as a result this suggests that there is a market available in plurisexual readers, who have instead been forced to seek out reading material that is not explicitly 'for them'.

Much of the queer fairy tale literature I have surveyed is not a comfortable space for plurisexual readers. Although the authors typically rely solely on behaviour between people of the same gender to depict sexuality, they also rely on erasure in more than just their titles as they attempt to invert heteronormativity and 'queer' their tales, creating environments where characters are presumed to be gay or lesbians. Although this does have the 
effect of challenging traditional expectations that all characters are heterosexual, both approaches erase plurisexual identities.

In 'The Man Who Was Lovers with a Pigeon', an uncle gives his nephews advice, saying that '...it may be some day what you want is one special man to make a life with' (Cashorali 1997a: 109). Similarly, in 'The Beauty in the Mountain of Ice', David is told that 'you may be lucky enough to come upon the perfect view... He'll be looking right into the camera at you' (Cashorali 1997b: 50). Both of these mentor figures expect that the protagonist will be interested in dating men, despite this never being discussed or suggested. In 'The Man Who Didn't Know the Meaning of Fear', it is also expected that the protagonist is interested solely in men, who is told to give the villain his boyfriend to avoid being eaten (Cashorali 1997b: 83).

Some stories in the survey not only imply that characters must only be interested in the same gender as themselves, but also remove all characters of other genders from their narratives entirely. This is particularly common in Cashorali's collections, which remove women not only as lovers (understandably) but as platonic friends or passers-by. In 'The Queer Garment', only men leave their houses to celebrate at the resolution of the tale (Cashorali 1997b: 23), 'The Man Who Didn't Know the Meaning of Fear' features a coffee shop entirely filled with men (Cashorali 1997b: 80), and 'The Radiant Boy' revolves around a dinner party where only men are invited (Cashorali 1997b: 126). Often roles traditionally held by women, such as the witch in 'Romaine' (Cashorali 1997a) and the fairy in 'The Beauty in the Mountain of Ice' (Cashorali 1997b) are transformed into men, which subverts gender roles, but excludes women and other gendered characters.

When women do feature in Cashorali's collections, they are the sisters, mothers and grandmothers of the protagonist, with this familial connection designed to position these women as impossible (or inappropriate) for the protagonist to be interested in romantically or sexually. These women often react negatively to the protagonist's same-gender attractions or ostracise the protagonist from their family or community. These tales imply that gay men - no longer requiring women for romantic relationships - seek a world where women do not exist at all. When these patterns dominate queer reimaginings of the fairy tale canon, it becomes difficult for queer readers who are not monosexual to engage in the content.

It's worth considering that this erasure of plurisexuality may be related to the general acceptance of plurisexual identities in the queer community and society in general at the time that these queer fairy tale collections were published (1997-2010); however, the young adult fiction considered in this paper that feature plurisexual characters has a publication window that overlaps this one (2005-2017) and suggests the erasure and otherwise problematic representation of plurisexuality may be changing.

\section{Misrepresentation}

In their attempts to feature same-gender attractions or relationships, much of the queer tales literature misrepresents queer identities, including the gay and lesbian identities that they are prioritising. Recurring instances of gender diversity as surprise reveals or plot twists, inappropriate language choices and unhealthy relationship structures demonstrate that existing collections of queer fairy tales are, overall, perpetuating discriminatory and stereotypical attitudes towards plurisexual, gender diverse and polyamorous people. 
In A Twist of Grimm: Erotic Fairy Tales for Gay Men, 'The Queer Kingdom' uses gender diversity as a plot twist when Sam - who identifies as a woman is seen to have 'masculine' facial features and 'sharp little blades of hairs rising to the surface' of her cheeks (Holden 2010: np). After revealing these traits, the narrator refers to the maiden as a 'man', regardless of previously stating that Sam identifies as a woman. 'The Androidgenous Zone' also includes incorrect pronouns: a gender ambiguous android is called 'lover boy' by the protagonist until she corrects herself, reflecting that she will "have to grasp the concept of Illiod being not a "he" but an "it"" (Hook \& Ashley 2008: 105); using 'it' to refer to an agender character instead of 'they' objectifies the character.

This clumsy navigation of transgender identity, including problematic misgendering, demonstrates that these tales are focused solely on sexuality and have not attempted to authentically explore gender diversity. In this way, existing collections of queer tales do not seek to dismantle 'heteronormative, patriarchal, hegemonic discourses' as Orme (2010: 123) suggests queer tales should, and do not recognise the 'shifting and fluid desires and identity formations of the marginalized'. In fact, through their misgendering and use of inappropriate language, such literature further marginalises people with diverse gender identities.

There are a number of other examples of inappropriate references to gender diversity in my sample - particularly Polluto 4 (Lowe, Hooper \& Diviney 2008). 'Queer and Loathing on the Yellow Brick Road' has an explicitly transgender character who experiences gender fluidity, preferring 'Osma' and she/her pronouns some days and 'Osaak' and he/him pronouns on others. Although the protagonist seems quick to accept these shifts in gender identity, the protagonist also frequently uses incorrect pronouns and derision when referring to Osma/Osaak, as demonstrated by the following line of dialogue: 'I understand the whole transgender thing, I really do. But why does switching off cause her to wear such horrible outfits?' (Hoag 2008: 34).

Another gender fluid character - this one in 'Beta Child, Gamma Child' - is referred to as 'one of these men [that] ain't a real man' (Edwards 2008: 50). This gender fluid character says that they do not want the protagonist to think of them as 'some confused, transgender he/she' (Edwards 2008: 51). 'He/she' is inappropriate language that should not be used to refer to gender diverse or intersex identifying people; this term was deemed a 'dehumanizing slur' by the Gay and Lesbian Alliance Against Defamation a year before Queer and Loathing was published (Grippi 2007).

\section{Conclusion}

The fairy tale genre remains an apt space for exploring how to modify genre conventions to better represent queer perspectives precisely because of a long tradition of conventions that perpetuate heteropatriarchal ideals. Many queer tales have been written in response to this potential, but their approach to destabilising heteropatriarchal conventions has frequently excluded plurisexual perspectives, actively marginalising those with diverse genders and prioritising explicit sexual acts, violent and unhealthy relationships, and inappropriate language for non-adult audiences.

Although the number of queer characters within young adult fiction is still small, it is also increasing, and seems to present increasingly varied and nuanced representations of queerness that can be accessed by a younger audience. The emphasis of self-identification within these texts contrasts with 
the behaviour-focused approach within the earlier canon of queer tale literature and aligns with the prioritisation of self-identification seen within the queer community through discourse analysis. Increasingly, new young queer stories, such as my own collection Queerly Ever After, focus on explicitly labelling identities, demonstrating how individuals might live queer lives without prejudice in fantasy landscapes, presenting queer relationships as able to be secondary to other action that is influencing the lives of characters, and exploring how teenagers can navigate their own identities and the potential stereotypes associated with those identities. These nuanced representations of queer characters and the interactions between these characters have a significant contribution to make in the ongoing mission to challenge heteropatriarchal conventions through the genre of the reimagined fairy tale.

\section{Notes}

[1] Plurisexuality refers to those who are attracted to more than one gender and works as an umbrella term for a number of multiple-gender-attracted identities (Mitchella, Davisa \& Paz Galupoa 2014: 11). There are many other umbrella terms that serve a similar purpose including bisexuality, polysexuality and non-monosexuality - but I deliberately use 'plurisexuality' in my written work at the present time to avoid the problems posed by many of the alternatives. The justification of this choice is explored in my doctoral thesis (Cole 2018). return to text

\section{Works cited}

Baker, DJ 2010 'Monstrous Fairytales: Towards an Ecriture Queer’, Colloquy: Text, Theory, Critique 20: 79-103 return to text

Barzak, C 2007 'Isis in Darkness', in S Berman (ed) So Fey: Queer Fairy Fiction Haworth Press, Philadelphia: 194-213 return to text

Belsey, C 2005 'Textual Analysis as a Research Method', in G Griffin (ed) Research Methods for English Studies Edinburgh University Press, Edinburgh: 157-74 return to text

Berman, S (ed) 2007 So Fey: Queer Fairy Fiction, Haworth Press, Philadelphia return to text

Best, S \& S Marcus 2009 'Surface Reading: An Introduction’, Representations 108, 1: 1-21 return to text

Black, H 2007 'The Coat of Stars', in S Berman (ed) So Fey: Queer Fairy Fiction Haworth Press, Philadelphia: 151-70 return to text

Block, FL 2013 Love in the Time of Global Warming, Henry Holt, New York return to text

Brien, DL 2006 'Creative Practice as Research: A Creative Writing Case Study', Media International Australia, Incorporating Culture \& Policy 118: 53-9 return to text

Callis, AS 2014 'Bisexual, Pansexual, Queer: Non-Binary Identities \& the Sexual Borderlands', Sexualities 17, 1/2: 63-80 return to text

Cardamone, T 2007 'A Faun's Tale', in S Berman (ed) So Fey: Queer Fairy Fiction, Haworth Press, Philadelphia: 14-6 return to text

Cashorali, P 1997a Fairy Tales: Traditional Stories Retold for Gay Men, HarperOne, New York return to text

Cashorali, P 1997b Gay Fairy \& Folk Tales: More Traditional Stories Retold for Gay Men, Faber \& Faber, London return to text

Cole, AM 2016 'Moving beyond the self: how blog posts can inspire narratives of representation', Proceedings of the 21st Australasian Association Of Writing Programs 
Conference, 1-11: http://www.aawp.org.au/wpcontent/uploads/2017/03/Cole_AAWP_2016_moving-beyond-the-self.pdf return to text

Cole, AM 2018 Queerly Ever After: An Exploration of Fairy Tales through a Plurisexual Lens [Doctoral thesis] Queensland, Australia: University of the Sunshine Coast. Available at http://research.usc.edu.au/vital/access/manager/Repository/usc:26186 return to text

Cranny-Francis, A 1992 Engendered Fiction: Analysing Gender in the Production and Reception of Texts, New South Wales University Press, Kensington NSW return to text

Curatolo, B 2012 'Queering “Happily Ever After”: Queer Narratives Expose Heteronormalcy in Fairy Tales', Senior Honors Project 3, Carroll Collected (Fall): http://collected.jcu.edu/honorspapers/3 (accessed 15 December 2015) return to text

Dagstine, LR 2008 'Heart of Cement', in A Lowe, V Hooper \& J Diviney (eds) Polluto 4: Queer and Loathing in Wonderland, Dog Horn Publishing, Leeds: 85-91 return to text

Edwards, M 2008 'Beta Child, Gamma Child', in A Lowe, V Hooper \& J Diviney (eds) Polluto 4: Queer and Loathing in Wonderland, Dog Horn Publishing, Leeds: 47-58 return to text

Eisner, S 2013 Bi: Notes for a Bisexual Revolution, Seal Press, New York return to text

Ford, AC 2015 'I'm Queer No Matter Who I'm With. I Won't Define Myself Differently for Your Comfort', The Guardian:

http://www.theguardian.com/commentisfree/2015/mar/14/queer-dating-spectrum-other-peoplecomfort (accessed 1 January 2016) return to text

Frick, CV 2007 'Attracting Opposites', in S Berman (ed) So Fey: Queer Fairy Fiction, Haworth Press, Philadelphia: 225-32 return to text

Grant, A 2006 'The Mute Princess', in J Vanderhooft, CM Valente, E YellowBoy \& J Talbot (eds) Sleeping Beauty, Indeed and Other Lesbian Fairytales, Lethe Press, Maple Shade: 33-48 return to text

Grimm J \& W Grimm 2013 'Cinderella', in The Complete Illustrated Works of the Brothers Grimm, Bounty Books, London: 114-21 return to text

Grippi, M 2007 'Glaad Condemns “Dehumanizing” Page Six New York Post Column', The Advocate: http://www.advocate.com/arts-entertainment/entertainment-news/2007/10/05/glaadcondemns-dehumanizing-page-six-new-york-post (accessed 30 December 2016) return to text

Hale, CJ 1997 'Leatherdyke Boys and Their Daddies: How to Have Sex without Women or Men', Social Text 52/53: 223-36 return to text

Hoag, D 2008 'Queer and Loathing on the Yellow Brick Road', in A Lowe, V Hooper \& J Diviney (eds) Polluto 4: Queer and Loathing in Wonderland, Dog Horn Publishing, Leeds: 3340 return to text

Holden, W 2010 A Twist of Grimm: Erotic Fairy Tales for Gay Men, Lethe Press, Maple Shade $\mathrm{NJ}$ return to text

Holsen, R 2006 'Two Sisters', in J Vanderhooft, CM Valente, E YellowBoy \& J Talbot (eds) Sleeping Beauty, Indeed and Other Lesbian Fairytales Lethe Press, Maple Shade NJ: 10-28 return to text

Hook, A \& A Ashley 2008 'The Androidgenous Zone', in A Lowe, V Hooper \& J Diviney (eds) Polluto 4: Queer and Loathing in Wonderland Dog Horn Publishing, Leeds: 103-11 return to text

Jiménez, LM 2015 'Representations in Award-Winning LGBTQ Young Adult Literature from 2000-2013', Journal of Lesbian Studies 19, 4: 406-22 return to text

Johnson, M 2005 The Bermudez Triangle, Penguin, London return to text

Johnson, M 2013 Biphobia and the Bermudez Triangle: An Open Letter to Maureen Johnson: http://maureenjohnsonbooks.tumblr.com/post/71321105195/biphobia-and-the-bermudeztriangle-an-open-letter (accessed 26 July 2017) return to text 
Kaye, A 2007 'From Asphalt to Emeralds to Moonlight', in S Berman (ed) So Fey: Queer Fairy Fiction, Haworth Press, Philadelphia: 118-35 return to text

Lo, M 2009 Ash, Hachette, London return to text

Lo, M 2011 I Have Numbers! Stats on Lgbt Young Adult Books Published in the U.S. - Updated 9/15/11: https:/www.malindalo.com/blog/2011/09/i-have-numbers-stats-on-lgbt-young-adultbooks-published-in-the-u-s (accessed 26 July 2017) return to text

Lo, M 2012 Adaptation, Hachette, London return to text

Lo, M 2013 Inheritance, Hachette, London return to text

Lo, M 2018 Hi Tinyqueerme: http://malindalo.tumblr.com/post/144663342248/i-loved-ash-andits-one-of-the-best-books-ive (accessed 26 July 2017) return to text

Lowe, A, V Hooper \& J Diviney (eds) 2008 Polluto 4: Queer and Loathing in Wonderland, Dog Horn Publishing, Leeds return to text

Lundoff, C 2007 'A Scent of Roses’, in S Berman (ed) So Fey: Queer Fairy Fiction, Haworth Press, Philadelphia: 16-28 return to text

Martin, KT 2015 Sexuality Profiling and the Issue of Stereotypes: http:/queervoices.com/2015/09/sexuality-profiling-and-the-issue-of-stereotypes/ (accessed 7 January 2016) return to text

Meriwether, S 2007 'Exiles', in S Berman (ed) So Fey: Queer Fairy Fiction, Haworth Press, Philadelphia: 244-58 return to text

Migman, D 2008 'Alice in the Palace', in A Lowe, V Hooper \& J Diviney (eds) Polluto 4: Queer and Loathing in Wonderland, Dog Horn Publishing, Leeds: 3-4 return to text

Mitchella, RC, KS Davisa \& M Paz Galupoa 2014 'Comparing Perceived Experiences of Prejudice among Self-Identified Plurisexual Individuals’, Psychology \& Sexuality 6, 3: 245-57 return to text

Monette, S 2007 'Three Letters from the Queen of Elfland', in S Berman (ed) So Fey: Queer Fairy Fiction Haworth Press, Philadelphia: 85-97 return to text

Moretti, F 2013 Distant Reading, Verso Books, New York return to text

Ochs, R 2009 Getting Bi: Voices of Bisexuals around the World, Bisexual Resource Center, Boston return to text

Orme, J 2010 'Mouth to Mouth: Queer Desires in Emma Donoghue's Kissing the Witch', Marvels \& Tales 24, 1: 116-30 return to text

Orndorff, K 1999 Bi Lives: Bisexual Women Tell Their Stories, See Sharp Press, Tucson AZ return to text

Perrault, C 1969 'Cinderella or the Little Glass Slipper', Perrault's Fairy Tales, Dover Publications, New York: $65-78$ return to text

Pinckard, A 2008 'Paint the Town', in A Lowe, V Hooper \& J Diviney (eds) Polluto 4: Queer and Loathing in Wonderland Dog Horn Publishing, Leeds: 59-61 return to text

Potter, E 2007 'Detox', in S Berman (ed) So Fey: Queer Fairy Fiction, Haworth Press, Philadelphia: 11-8 return to text

Smith, H \& RT Dean 2009 Practice-Led Research, Research-Led Practice in the Creative Arts, Edinburgh University Press, Edinburgh return to text

Talley, R 2017 Our Own Private Universe, Harlequin Enterprises, Toronto return to text

Trooien, K 2016 Making Assumptions of Sexuality:

http://dakotastudent.com/5161/opinion/making-assumptions-of-sexuality/ (accessed 7 January 2016) return to text 
Vanderhooft, J, CM Valente, E YellowBoy \& J Talbot (eds) 2006 Sleeping Beauty, Indeed and Other Lesbian Fairytales, Lethe Press, Maple Shade NJ return to text

Wiest, B 2013 “"Sexual-Profiling” and Why We Must Stop Making Assumptions Based on Appearance', Thought Catalogue (23 August): http://thoughtcatalog.com/briannawiest/2013/08/sexual-profiling-and-why-we-must-stop-making-assumptions-based-onappearances/ (accessed 7 January 2016) return to text

Woods, KD 2007 'The Kings of Oak and Holly', in S Berman (ed) So Fey: Queer Fairy Fiction, Haworth Press, Philadelphia: 97-111 return to text

Zipes, J 1999 When Dreams Came True: Classical Fairy Tales and Their Tradition, Routledge, New York return to text

Zucker, KJ, AA Lawrence \& BP Kreukels 2016 'Gender Dysphoria in Adults', Annual review of clinical psychology 12: 217-47 return to text

Dr Alayna Cole is a sessional course coordinator and lecturer in Serious Games at the University of the Sunshine Coast. She holds a doctorate in Creative Arts (Creative Writing) and has broad research interests, but is primarily focused on creating and analysing narratives that improve diverse representation, particularly of gender and sexuality. She is currently researching the representation of queer identities in games from the mid-1980s to present.

\section{TEXT}

Vol 22 No 2 October 2018

http://www.textjournal.com.au

General Editor: Nigel Krauth. Editors: Julienne van Loon \& Ross

Watkins

text@textjournal.com.au 